\title{
Automated microbiological assay of thiamin in serum and red cells
}

\author{
G Icke, D Nicol
}

\begin{abstract}
Aims-To develop a sensitive, direct, automated method for the measurement of serum and red cell thiamin.

Methods-A microbiological assay using a chloramphenicol resistant strain of Lactobacillus fermenti as the test organism was developed. Addition of chloramphenicol and cycloheximide to the assay medium suppressed bacterial and yeast contamination and enabled tests to be automated without recourse to aseptic procedures. Evaluation of the assay included precision analysis and estimation of thiamin recovery. Results obtained on red cell extracts were compared with an established colorimetric (thiochrome) method.

Results-Acceptable intrabatch and interbatch precision was obtained and good recovery of thiamin added to serum was obtained. Non-parametric reference ranges based on the results from 505 healthy people were: serum thiamin 11.3-35.0 nmol/l and red cell thiamin 190-400 nmol/l. Results were not age or gender related. The method gave results for red cell thiamin which were significantly higher than those obtained with an established thiochrome method.

Conclusions-This automated microbiological assay is sensitive to $2.0 \mathrm{nmol} / 1$ of thiamin and allows tests to be set up at the rate of 100 per hour and after 20-22 hours allows incubation results to be read at 60 per hour. The method has proved reliable, suitable for the assay of large numbers of samples, and relatively inexpensive to perform.
\end{abstract}

(F Clin Pathol 1994;47:639-641)

Several methods have been proposed for the determination of thiamin concentration in man. An indirect approach has often been used, involving the measurement of red blood cell transketolase activity. ${ }^{2}$ Although convenient to perform, other non-thiamin dependent enzymes may interfere and several reports have appeared which cast doubt on the validity of this test. Leevy et $a l^{\beta}$ reported that there was no correlation between blood thiamin (as measured by microbiological assay with Ochromonas danica) and red cell transketolase activity in hospital patients. Baker also noted a similar discrepancy, especially in patients with liver disease. ${ }^{4}$
Direct methods based on the oxidation of thiamin to its fluorescent derivative thiochrome have also been used. ${ }^{5-8}$ The major drawback with most thiochrome methods has been poor sensitivity, making them unsuitable for assay of concentrations found in plasma. More recently increased sensitivity has been achieved by coupling high pressure liquid chromatography (HPLC) separation with thiochrome derivatisation..$^{9-11}$

Several microbiological methods for thiamin assay have been described. ${ }^{12-15}$ However, to date none has gained widespread acceptance largely due to methodological complexities.

\section{Methods}

The assay organism used was a chloramphenicol resistant strain of Lactobacillus fermenti developed from a standard strain obtained from the American Type Culture Collection (ATCC 9338). Chloramphenicol resistance was achieved using the method described by Davis $e t a l^{16}$ and the organism was maintained by drying on to small ceramic beads. ${ }^{17}$

Double strength assay medium was prepared according to the protocol shown in table 1. Solution was effected using a magnetic stirrer without heating.

\section{Table 1 Preparation of assay medium}

\begin{tabular}{|c|c|}
\hline $\begin{array}{l}\text { Glucose } \\
\text { Sodium acetate } \\
\text { Maltose } \\
\text { Casamino acids (vitamin free) } \\
\text { Casein hydrolysate enzymatic (vitamin free) })^{\star \star} \\
\text { Di-potassium hydrogen phosphate } \\
\text { Potassium di-hydrogen phosphate } \\
\text { Ascorbic acid } \\
\text { Magnesium sulphate }\left(7 \mathrm{H}_{2} \mathrm{O}\right) \\
\text { L-cysteine } \\
\text { L-cystine } \\
\text { L-tryptophan } \\
\text { Manganous sulphate }\left(\mathrm{H}_{2} \mathrm{O}\right) \\
\text { Adenine sulphate } \\
\text { Guanine hydrochloride† } \\
\text { Uracil } \\
\text { Sodium chloride } \\
\text { Ferrous sulphate }\left(7 \mathrm{H}_{2} \mathrm{O}\right) \\
\text { Riboflavin } \\
\text { Nicotinic acid } \\
\text { Pyridoxine hydrochloride } \\
\text { Calcium D pantothenate } \\
\text { Biotin } \\
\text { Folic acid } \\
\text { Tween } 80 \\
\text { Distilled water (make up volume to) } \\
\text { Adjust pH to } 6 \cdot 5 \text { with } 8 \text { mol } / 1 \text { potassium hydroxide } \\
\text { dispense into } 250 \text { ml amounts and store at }-20^{\circ} \mathrm{C}\end{array}$ & $\begin{array}{l}200 \mathrm{~g} \\
100 \mathrm{~g} \\
50 \mathrm{~g} \\
25 \mathrm{~g} \\
250 \mathrm{ml} \\
5 \mathrm{~g} \\
5 \mathrm{~g} \\
2 \mathrm{~g} \\
2 \mathrm{~g} \\
5 \mathrm{~g} \\
1 \mathrm{~g} \\
125 \mathrm{mg} \\
125 \mathrm{mg} \\
100 \mathrm{mg} \\
100 \mathrm{mg} \\
100 \mathrm{mg} \\
50 \mathrm{mg} \\
50 \mathrm{mg} \\
1 \mathrm{mg} \\
1 \mathrm{mg} \\
1 \mathrm{mg} \\
1 \mathrm{mg} \\
4 \mu \mathrm{g} \\
2.5 \mu \mathrm{g} \\
5 \mathrm{ml} \\
5 \mathrm{litres} \\
\end{array}$ \\
\hline
\end{tabular}

Perth Hology,

Wellington Street

Perth, Western

Australia

G Icke

D Nicol

Accepted for publication

14 December 1993
${ }^{\star}$ Difco Laboratories, Detroit, Michigan, USA

$\star \star I C N$ Biomedicals, Costa Mesa, California, USA, (5\% sterile solution)

†Dissolve by suspending in a small volume of water and then adding $8 \mathrm{~mol} / \mathrm{l}$ potassium hydroxide dropwise until solution is complete. 
For maintenance of the test organism in liquid culture, chloramphenicol $(30 \mathrm{mg} / \mathrm{l})$ and cycloheximide $(30 \mathrm{mg} / \mathrm{l})$ were added to single strength assay medium which had been supplemented with thiamin nitrate $(10 \mathrm{nmol} / \mathrm{l})$.

On the day before the test, a tube containing $10 \mathrm{ml}$ of maintenance medium was inoculated with one ceramic bead coated with the dried organism. After overnight incubation the suspension was centrifuged at $1200 \times g$ for five minutes, the supernatant fluid discarded, and the organism resuspended in single strength assay medium. The absorbance $(700 \mathrm{~nm})$ of the suspension was adjusted to $0 \cdot 68-0 \cdot 70$.

Blood was collected into plain disposable phials. Serum was separated and stored at $-20^{\circ} \mathrm{C}$ until required for assay.

For red cell thiamin, $5 \mathrm{ml}$ of heparin or EDTA anticoagulated blood was collected and centrifuged at $1200 \times g$ for 10 minutes. The plasma and buffy coat layers were removed and discarded. Packed red blood cells $(0.5 \mathrm{ml})$ were diluted in $4.5 \mathrm{ml}$ of acetate buffer $(0.05 \mathrm{~mol} / \mathrm{l}, \mathrm{pH} 5.0)$ and mixed well. This preparation was stored at $-20^{\circ} \mathrm{C}$ until required for assay. On the day of the assay, red cell dilutions were thawed, mixed well, heated at $90^{\circ} \mathrm{C}$ for five minutes, allowed to cool, and centrifuged at $1200 \times g$ for $10 \mathrm{~min}-$ utes. The supernatant fluid was separated and assayed as for serum.

Thiamin mono-nitrate $(2.0 \mathrm{mmol})$ was dissolved in 1 litre of $1.6 \mathrm{mmol} / 1$ hydrochloric acid. This stock standard solution has been found to be stable for at least two years at $4^{\circ} \mathrm{C}$. On the day of the assay the stock standard was diluted 1 in 10000 in distilled water. This working solution was used to prepare standard solutions containing: $5,10,15$, $20,40,60,80$ and $120 \mathrm{nmol} / 1$.

A Gilson model 222 robotic diluting system, linked to a Gilford Stasar III spectrophotometer and controlled by an Epson PC, was used for setting up and reading the results of the assay.

Serum samples, red cell extracts, and standards were presented to the analyser in $2.5 \mathrm{ml}$ capacity disposable analyser cups and dilutions were made into $9 \mathrm{ml}$ capacity polypropylene tubes loaded into 44 place racks.

To each litre of single strength assay medium was added $10 \mathrm{mg}$ of chloramphenicol base, $10 \mathrm{mg}$ of cycloheximide, and $0.8 \mathrm{ml}$ of an overnight culture of the test organism which had been adjusted to a standardised absorbance (see preparation of inoculum). The organism was kept in suspension by the use of a magnetic stirrer.

The system was programmed to sample $0 \cdot 2$ $\mathrm{ml}$ of serum, red cell extract, or standard solution and dilute it with $4.8 \mathrm{ml}$ of the inoculated assay medium. Standards were set up in triplicate. A control serum was included after every 10 test samples.

After dilution assay racks were removed to a $37^{\circ} \mathrm{C}$ incubator for $20-22$ hours. The racks were then returned to the Gilson system which was programmed to mix the contents of each tube and record absorbance readings at $640 \mathrm{~nm}$. To increase precision, five readings for each tube were taken over two seconds. Samples were flagged where any reading greater than 0.02 absorbance units from the mean of the five absorbance readings was obtained. The interfaced PC was programmed to generate results by interpolation from the standards.

Intrabatch precision was determined by assaying one serum sample 24 times in one batch; the interbatch precision was determined using three serum samples (one in the deficient range, one borderline normal and one clearly normal) which were aliquoted and stored at $-20^{\circ} \mathrm{C}$ and assayed 12 times in different batches over nine months.

To determine recovery thiamin pyrophosphate (the biologically active and most abundant intracellular form of the vitamin) was added to four serum samples which had been previously assayed.

Ten red cell samples were assayed by both the microbiological and an established thiochrome method. ${ }^{6}$ Due to the insensitivity of this thiochrome method it was not possible to compare results obtained with serum samples.

To determine reference ranges, serum and red cell thiamin was assayed on 505 apparently healthy individuals ranging in age from 18 to 90 years.

\section{Results}

The intrabatch coefficient of variation (CV) was $3.4 \%$ (range $16 \cdot 2-18 \cdot 1 \mathrm{nmol} / 1$, mean (SD) $17 \cdot 1(0.56))$ The interbatch precision is shown in table 2 . Acceptable reproducibility was obtained at all thiamin concentrations.

Results for the recovery of thiamin pyrophosphate are shown in table 3 . Recovery ranged from 101 to $110 \%$.

Table 2 Interbatch precision of microbiological assay

\begin{tabular}{ccclc}
\hline Mean thiamin (nmolll) & No & Range & (SD) & $C V(\%)$ \\
\hline 5.69 (serum) & 12 & $4.5-6.4$ & $(0.57)$ & $10 \cdot 0$ \\
13.57 (serum) & 12 & $12 \cdot 1-15 \cdot 1$ & $(0.94)$ & 6.9 \\
26.0 (serum) & 12 & $24.9-28.3$ & $(1.58)$ & 6.1 \\
154.5 (red cell) & 19 & $131.9-173.3$ & $(11.46)$ & 7.4 \\
\hline
\end{tabular}

Table 3 Recovery of thiamin pyrophosphate added to Table
serum

\begin{tabular}{lcccl}
\hline $\begin{array}{l}\text { Sample } \\
\text { No }\end{array}$ & $\begin{array}{l}\text { Initial } \\
\text { assay } \\
\text { (nmoll) })\end{array}$ & $\begin{array}{l}\text { Thiamin } \\
\text { added } \\
\text { (nmoll) }\end{array}$ & $\begin{array}{l}\text { Repeat } \\
\text { assay } \\
\text { (nmoll) })\end{array}$ & $\begin{array}{l}\% \\
\text { Recovery }\end{array}$ \\
\hline 1 & $3 \cdot 8$ & $40 \cdot 0$ & $47 \cdot 7$ & 110 \\
2 & $3 \cdot 8$ & $20 \cdot 0$ & $24 \cdot 0$ & 101 \\
3 & $55 \cdot 8$ & $100 \cdot 0$ & $160 \cdot 5$ & 105 \\
4 & $43 \cdot 3$ & $75 \cdot 0$ & $124 \cdot 4$ & 108 \\
\hline
\end{tabular}

Table 4 Comparison of thiochrome and microbiological assay results

\begin{tabular}{lll}
\hline & \multicolumn{2}{l}{ Red cell thiamin (nmol/l) } \\
\cline { 2 - 3 } Sample & $\begin{array}{l}\text { Thiochrome } \\
\text { method }\end{array}$ & $\begin{array}{l}\text { Microbiological } \\
\text { method }\end{array}$ \\
\hline 1 & 279 & 369 \\
2 & 211 & 268 \\
3 & 170 & 226 \\
4 & 260 & 332 \\
5 & 226 & 298 \\
6 & 128 & 173 \\
7 & 252 & 347 \\
8 & 188 & 252 \\
9 & 305 & 415 \\
10 & 203 & 286 \\
\hline
\end{tabular}


Results for the comparison with a thiochrome method are shown in table 4 . Although correlation between the two methods was good $(r=0.99)$, the microbiological assay gave results which were $21-28 \%$ higher than the thiochrome method. The slope of the correlation line was 1.33 (SE 0.064) and the intercept was $1 \cdot 16$ (SE 14.61).

No correlation was observed between serum or red cell thiamin and age and there was no significant difference between the serum or red cell thiamin of men and women (Student's $t$ test). Reference ranges (nonparametric estimates) of $11.3-35.0 \mathrm{nmol} / 1$ for serum and 190-400 nmol/1 for red cells were adopted.

\section{Discussion}

The major drawback of most previously described methods for the direct measurement of thiamin in blood, both conventional thiochrome and HPLC methods, has been poor sensitivity. ${ }^{61819}$ At best, these methods can measure thiamin in whole blood but not in serum where concentrations are only $10 \%$ of those found in red cells. The development of improved HPLC procedures incorporating thiochrome derivatisation has addressed this problem..$^{9-11}$ However, HPLC requires considerable investment in instrumentation and is outside the scope of many smaller laboratories. Although the microbiological method described here has been automated using a robotic liquid handling system for high throughput, it can be easily performed using manual pipetting. Adaptation of the assay to microtitre plates as has been recently described for folate assay ${ }^{20}$ would offer greatly improved efficiency and work is continuing on this modification.

It has already been shown that the thiamin activity of red cells is stable at $90^{\circ} \mathrm{C}$ for up to 20 minutes under conditions of the assay method but declines by up to $30 \%$ by 30 minutes. ${ }^{21}$ The higher red cell thiamin concentrations obtained by the present method when compared with those obtained by the thiochrome method are probably due to the destruction of thiamin during the heat hydrolysis stage of the latter method. In the new microbiological method samples are heated at $90^{\circ} \mathrm{C}$ for only five minutes. Comparisons with serum thiamin concentrations were not possible due to the insensitivity of the thiochrome method used. The new method was sensitive to $2 \cdot 0 \mathrm{nmol} / 1$ of thiamin. The concentration of total thiamin found in the serum of healthy subjects $(11.3-35.0 \mathrm{nmol} / \mathrm{l})$ compares well with concentrations reported using sensitive HPLC methods. Weber and Kewitz ${ }^{9}$ reported a range of $6 \cdot 6-42.0 \mathrm{nmol} / 1$ and Bettendorff et $a l^{11}$ reported a range of 5.9-20.7 nmol/1. It should be noted, however, that these data were derived from the study of relatively small numbers (91 subjects and 42 subjects, respectively).
One of the drawbacks of all microbiological assays is the potential for organism inhibition by therapeutic drug concentrations in blood (particularly antibiotics) and this must be taken into account in the interpretation of low results. This inhibition usually only occurs with serum assay. With red cell assay, the greater dilution used minimises the problem. Repeat assay using a different dilution of test material is usually sufficient to alert to the presence of inhibitors.

Using the method described, it is possible to set up assays at the rate of 100 per hour and, after 20-22 hours of incubation, read at 60 per hour. The method is particularly well suited for use in population and institutional surveys.

The automated microbiological method has been used in this laboratory for a number of years and to date more than 60000 assays have been performed. The test has proved a reliable and relatively inexpensive addition to the diagnostic repertoire of the laboratory.

1 Brin M. Erythrocyte transketolase in early thiamine deficiency. Ann NY Acad Sci 1962;98:528-41.

2 Dreyfus PM. Clinical application of blood transketolase determinations. N Engl 7 Med 1962;267:596-8.

3 Leevy CM, Cardi L, Frank O, Gellene R, Baker $H$ Incidence and significance of hypovitaminemia in a randomly selected municipal hospital population. $\mathrm{Am} \mathcal{f} \mathrm{Cli}$ Nutr 1965;17:259-71

4 Baker H. Biochemical alterations in thiamine deficiencyby Sauberlich HE, discussion by Baker. Am $\mathcal{f}$ Clin Nutr 1967;20:525-43.

5 Hennessy DJ, Cerecedo LR. The determination of free and phosphorylated thiamin by a modified thiochrome assay. F Am Chem Soc 1939;61:179-83.

6 Schultz AL, Natelson S. Studies on the distribution and concentration of thiamine in blood and urine. Microchem I 1972;17:109-18.

7 Pelletier O, Madere R. New automated method for measuring thiamine in urine. Clin Chem 1972;18:937-42.

8 Leveille GA. Modified thiochrome procedure for the determination of urinary thiamine. Am $\mathfrak{f}$ Clin Nutr 1972;25:273-4.

9 Weber W, Kewitz H. Determination of thiamine human plasma and its pharmacokinetics. Eur $\mathcal{f}$ Clin Pharmacol 1985;28:213-9.

10 Tallaksen CME, Bøhmer T, Bell H. Concomitant determination of thiamin and its phosphate esters in human blood and serum by high-performance liquid chromatography. 7 Chromatogr 1991;564:127-36.

11 Bettendorff L, Grandfils C, de Rycker C, Schoffeniels E. Determination of thiamine and its phosphate esters in human blood serum at femtomole levels. $¥$ Chromatogr human blood serum

12 Sarrett $\mathrm{P}$, Cheldelin VH. The use of Lactobacillus fermentum 36 for thiamine assay. $¥$ Biol Chem $1944 ; 155: 153-9$.

13 Hoff-Jorgensen E, Hansen B. A microbiological assay for vitamin B1. Acta Chem Scand 1955;9:562-6.

14 Deibel RH, Evans JB, Niven CF jnr. Microbiological assay for thiamine using Lactobacillus viridescens. $\mathcal{F}$ Bacteriol 1957;74:818-21.

15 Baker H, Frank O, Fennelly J, Leevy CM. A method for assaying thiamine status in man and animals. Am $\mathcal{f}$ Clin Nutr 1964;14:197-9.

16 Davis RE, Nicol DJ, Kelly A. An automated method for the measurement of folate activity. $f$ Clin Pathol 1970;23:47-53.

17 Annear DI. Recoveries of bacteria after drying on cellulose fibres. Aust ₹ Exp Biol Med Sci 1962;40:1-8.

18 Roser RL, Andrist AH, Harrington WH. Determination of urinary thiamine by high-pressure liquid chromatography utilising the thiochrome flourescent method. $f$ Chromatogr 1978;146:43-53.

19 Kimura M, Itokawa Y. Determination of thiamine and its phosphate esters in human and rat blood by high performance liquid chromatography with post-column derivatization. $\mathcal{f}$ Chromatogr 1985;332:181-8.

20 O'Broin, Kelleher B. Microbiological assay on microtitre plates of folate in serum and red cells. $\mathcal{f}$ Clin Pathol 1992;45:344-7.

21 Icke GC. The microbiological assay of thiamine and its clinical significance. MSc thesis: University of Western Australia, 1980. 